\title{
SEKULARIZACIJA I MORAL
}

\section{Mihael Antolović, Slobodan Sadžakov}

Pedagoški fakultet Sombor,

Univerzitet u Novom Sadu, Srbija

mihael.antolovic@pef.uns.ac.rs;

slobodansadzakov@yahoo.com

Iako su tekovine sekularizacije etablirane kao integralni dio stvarnosti modernih društava, prisutne su i brojne tendencije usmjerene ka tome da se ona ospori i obezvrijedi. Te tendencije, koje mogu imati ozbiljne posljedice, uključuju mišljenje da sekularizacija ne predstavlja nešto neupitno. Zato se čini potrebnim podsjetiti na njene legitimacijske osnove, tim prije jer je riječ o temi koja ne predstavlja samo akademsko pitanje nego $i$ nešto što na bitan način zadire u temelje organizacije $i$ kvalitete svakodnevnog života. U ovome radu posebno ćemo se osvrnuti na etičke aspekte sekularizacije, odnosno na odnos sekularizacije i morala.

Ključne riječi: moral, sekularizacija, pravo, religija, kršćanstvo

1.

Na samom početku rada potrebno je u kratkim crtama ukazati na ono što se smatra civilizacijskim značajem i smislom sekularizacije. $\mathrm{Da}$ bi se bolje razumio proces sekularizacije, potrebno je prisjetiti se nekoliko važnih toposa povijesti europske civilizacije, posebno onih koji se tiču religije (crkve). Najprije činjenice da poslije prvobitnog progona ranih kršćana i njihova učenja, kršćanstvo 313. godine postaje državnom religijom (Veyne, 2013, 312-394; Lynch, 1999). Tada, »konstantinovskim zagrljajem «, za kršćanstvo počinje sasvim drugačije razdoblje u odnosu na vrijeme progona. To razdoblje obilježeno je dugotrajnim povijesnim prožimanjem »duhovne« $\mathrm{i} »$ svjetovne « moći, crkve i države. On je podrazumijevao različite oblike simbioze, ali i brojne 
napetosti i sukobe ovih dviju moći. ${ }^{1}$ Za našu temu posebno je važno razdoblje Srednjeg vijeka na europskom tlu, koje prethodi vremenu u kojemu se odigrao proces sekularizacije. Srednji vijek bio je obilježen dominacijom kršćanskog idejnog okvira, koji je na mnogo načina utjecao na praktička izražavanja, što je, pored ostalog, podrazumijevalo i utjecaj na formiranje moralnih stavova i djelovanja. Kao veliki povijesni odgovor na razdoblje srednjovjekovnog primata »teologijske slike sveta« otpočinje proces sekularizacije koji donosi postepeno slamanje temelja srednjovjekovnih načina mišljenja i poredaka praktičkog djelovanja (Borkenau, 1983). Navedeni proces bio je višestran i uključivao brojne dimenzije: političku, pravnu, ekonomsku, moralnu, znanstvenu, filozofsku itd.

Kao ključno, nameće se pitanje: zašto je utjecaj religije morao biti relativiziran, odnosno zašto dolazi do procesa sekularizacije? Najuopćeniji odgovor mogao bi biti hegelovskog tipa: zato jer je religijski primat u jednom trenutku europske povijesti prepoznat kao velika prepreka razvoju slobode, odnosno razmahu novih tendencija društvenosti (u sferi znanosti, politike, morala, ekonomije). Naravno, ovu tvrdnju treba pojasniti i argumentirati što ćemo i nastojati učiniti u nastavku rada.

2.

Povijest religije predstavlja mješavinu kultivizacije ljudske svijesti, s jedne strane, i ozbiljnih jednostranosti, s druge. Kada govorimo o kultivizaciji ljudske svijesti, treba spomenuti da je u okviru kršćanske religije iskazana ideja egaliteta (Sadžakov, 2006, 165-179). Ta ideja, koja je isto što i ideja čovjeka, donosi stav da su ljudi kao »božja bića« izjednačeni unatoč svojim klasnim, spolnim, etničkim itd., razlikama. Iako skromnih neposrednih konsekvenci u pogledu društvenosti tadašnjega vremena, ideja egaliteta važna je zbog toga što su ljudi po prvi puta u povijesti na određeni način izjednačeni. ${ }^{2}$ Kasnije je ta ideja imala svoje raznovrsne odjeke, postajala dio »opće svijesti« i svojevrsna osnova društvenosti. S druge strane, različita religijska uvjerenja i tumačenja često su tijekom povijesti, kao i danas, bila uzrokom velikih

\footnotetext{
${ }^{1}$ Spomenimo ovdje samo činjenicu da je Grgur VII proglasio pape vladarima nad svjetskim kraljevstvima i u svom Dictatus papae ekskomunicirao Henrika IV. O napetostima crkve i države kroz povijest više u: Brown, 2010; Franzen, 1983; Boisset, 1985.

${ }^{2}$ Određeni nagovještaj ove ideje može se prepoznati i u okviru stoičke filozofije. Usp. Pannenberg, 2003, 67-79.
} 
sukoba, progona, ratova. To je u pravilu donosilo ozbiljna ograničavanja slobode mišljenja (uvjerenja, savjesti) i djelovanja, s često fatalnim posljedicama (proganjanje i spaljivanje onih koji su se suprotstavljali crkvenim učenjima). Važno pitanje u ovome kontekstu je: Jesu li ove pojave dolazile direktno iz duha određenih religija ili su one njihova zastranjenja odnosno iznevjeravanje smisla (koje se događalo i u slučajevima pokušaja realizacije nekih političkih koncepata)? Drugim riječima, je li riječ o nečemu što potječe iz »prljavštine prakse« ili određeni aspekti religijskih učenja doista sadrže ozbiljne »nanose« fundamentalizma, ograničavanja slobode, totalitarizma?

S obzirom na spomenute opasnosti i opsežnu fenomenologiju religijske prakse, u određenom povijesnom razdoblju europske civilizacije počela je jačati svijest o potrebi ograničavanja utjecaja Crkve, odnosno o omogućavanju prava na slobodu vjere (slobodno izabrano religijsko uvjerenje kao privatno pitanje), ali i prava na slobodu od vjere (agnosticizam, ateizam). To je ostvarivano kroz proces koji se naziva sekularizacija. Proces sekularizacije je u osnovi podrazumijevao: eksproprijaciju (oduzimanje) crkvene imovine, razdvajanje državnih i crkvenih ingerencija u pogledu političke vladavine, te laizaciju (posvjetovljenje) obrazovnog procesa. Strukturno gledano, sekularizacijom se crkva iz simbiotičke veze s državom (koja je nerijetko podrazumijevala i napetosti oko primata) smješta »stepenicu niže«, u građansko društvo. Time njeno mjesto, uloga i mogućnosti postaju sasvim drugačije.

3.

Monoteističke religije su, kao što je poznato, zasnovane na uvjerenju o postojanju jednog boga. Također, jedna od temeljnih postavki monoteizma je stav o stvorenosti čovjeka od strane boga i imperativ »okrenutosti« njemu, prvenstveno kroz ispunjavanje božjih »naloga«. Pravila monoteističkih religija (upute o dobrom, valjanom, poželjnom) iskazana su kroz tekstove koje određeni vjerski pravci nazivaju svetim knjigama (Biblija, Kuran). To podrazumijeva i uvjerenje da njihov sadržaj potječe od boga kao apsoluta koji je preko proroka (Mojsije, Isus, Muhamed) iskazao svoju »volju«. Ove knjige predstavljaju idejnu osnovu osmišljavanja prakse crkvi. Crkva, u osnovi, predstavlja izraz institucionalizacije vjere i zasnovana je na brojnim dogmatskim pravilima kojih bi se, kako se smatra, vjernici trebali pridržavati. Dogma pokazuje 
pretenziju na istinu, pretenziju na to da predstavlja cjelovito i uvjerljivo objašnjenje postojanja i svrhe čovjeka i »svijeta«, kao i ispravno moralno stajalište, odnosno moralnu istinu. Iako teologija podrazumijeva permanentnu egzegezu, neke dogmatske postavke ostaju nepromijenjene kao ono što se smatra za srž određene religije. Pretenziju na istinu (uključujući i moralnu istinu) koja se rađa u krilu religije važno je ovdje komparirati sa znanošću, kao jednom od »poluga« modernog doba. Poznato je da znanstveno mišljenje također podrazumijeva upućenost na istinu. Postavlja se pitanje kako shvatiti spomenutu pretenziju, bilo da ona dolazi iz sfere religije ili sfere znanosti. Je li uvjerenje o postojanju određenih istina nešto što je loše samo po sebi? Kada takvo uvjerenje eventualno postaje problemom s ozbiljnim društvenim posljedicama? Kakve su sličnosti i razlike znanosti i religije u tom pogledu, je li riječ o njihovoj suprotstavljenosti?

Smatramo da je religijska verzija istine, prikazana kao dogma, $u$ bitnom suprotstavljena znanstvenom traganju za istinom. U naporu spoznaje objektivne stvarnosti, znanstvene procedure i verifikacije rezultata istraživanja temelje se na potpuno drugačijim osnovama od onih na koje se oslanja teologija (Cohen i Nagel, 1965, 218-240). Znanstvena spoznaja podrazumijeva kontinuirano preispitivanje vlastitih rezultata i njihovo korigiranje, za razliku od sfere religije koja se, počev od stava »Ja vjerujem« (kao emocionalnog iskaza koji se ne može provjeriti) do sustavnih teoloških postavki, zadržava u samorazumljivosti svojih tvrdnji, odnosno u mediju teško dokazivog i opovrgljivog u pogledu istinitosti. Nasuprot znanstvenom putu do istine, dogma je u svojoj suštini suprotna istini jer je »okamenjen skup stavova koji ne dopušta kritiku « (M. Kangrga). Epstein primjećuje da je historija mišljenja »historija borbe misli protiv vlastitog okamenjivanja i obesmišljavanja u oblicima raznih ideologija i mitologija, teoloških i metafizičkih dogmi« (Epstein, 2009, 21). Novovjekovno razvijanje znanstvene metode, temeljeno na razumskoj verifikaciji, trasiralo je sasvim drugačiji put u odnosu na nesigurne osnove teološkog utemeljenja istine, odnosno presudno utjecalo na suštinsko razdvajanje znanosti i vjere (dogme, religijskog načina mišljenja). U ovom kontekstu možemo podsjetiti i na činjenicu da je teološko mišljenje, suočeno s rezultatima znanstvenih spoznaja i dostignuća, mijenjalo neka svoja stajališta. Međutim, određene dogmatske postavke su zadržavane, s ambicijom da budu orijentir i imaju značajnu društvenu relevantnost i utjecaj. 
Na kraju ovoga poglavlja možemo primijetiti da je tijekom povijesti pa sve do današnjih dana problem nastajao onda kada se pretenzija na istinu koja je dolazila iz sfere religije spajala s realnom političkom moći, odnosno s mogućnostima represije u formi države ili određene društvene grupacije. Takvo »protezanje« religijskih pretenzija i spajanje s represijom najčešće je završavalo kao prinuda, teror, progon, ekskomunikacija, nametanje općeobvezujućih »istina« itd.

\section{4.}

Razmotrimo sada neke karakteristike sfere morala, kao i transformacije ove forme društvenosti kroz povijest. Od svoga postanka, odnosno javljanja moralnog fenomena u razdoblju Antike sa Sokratom, ovo stajalište na bitan način podrazumijeva individualizaciju (moralnu samosvijest). Sa Sokratom se moralna svijest na specifičan način konstituira kao opreka običajnosno-kolektivnim obrascima življenja. Samorazumljivosti i uniformnosti dotadašnjeg načina života, usklađenog s običajima otaca (tradicijom), Sokrat suprotstavlja refleksiju (pojam), odnosno preispitivanje stvarnosti (odnosno vrijednosti koje je konstituiraju). On time zagovara stav da moralna samosvijest donosi ključnu mogućnost da se moralna uvjerenja i izbori odrede samostalno, a ne po »inerciji« uhodanog načina života. Već na samom početku rađanja moralnog fenomena, iskazani su, dakle, suštinski elementi toga stajališta, kao prolegomena svih kasnijih utemeljenja. Nakon Sokrata, s Kristovim učenjem, u religijskoj sferi obnavlja se potraga za moralnom individualnošću. To učenje se, s jedne strane, formira u razlici spram neduhovnog formalizma farizeja (kao nositelja židovske običajnosti), a s druge u razlici spram svjetovne moći rimske vlasti. Kristova poruka donosi stav da se bistvenost, istinski život i moralnost nalaze s onu stranu koordinata židovskog običajnog formalizma i državne moći Rima. Pretenzija na istinu iskazana u Novom zavjetu isto je što i pretenzija na moralnu istinu. To presudno određuje kako »opći duh« toga spisa tako i nastup kršćanske religije prema »praktičkom svijetu«.

Krist se obraća srcu, ljudskoj unutrašnjosti, obećavajući individualizirano spasenje kao nagradu za moralan život odnosno izvršavanje božanskih »naloga«. Ovaj tip nagovora na moralnu individualnost fundamentalno je utemeljen preko određenja boga kao moralnog apsoluta i smisla života. Kristov poziv na okretanje bogu kao pretpostavci 
zasnivanja istinskog moralnog djelovanja, podrazumijevao je i stav o indiferentnosti prema sudjelovanju u praktičkom životu kroz sfere politike, prava i ekonomije. Osnovni razlog za to bio je jak eshatološki naboj koji je obilježavao prvobitno kršćanstvo, što je podrazumijevalo stav da je okretanje moralnim svrhama (vjernost bogu, ljubav prema bližnjem) jedino smisleno ponašanje kao uvjet spasenja, dok je sve drugo proglašeno efemernim. Međutim, sa splašnjavanjem eshatološkog naboja, što je primjetno već u Pavlovim poslanicama, uviđa se nužnost nalaženja formi koegzistiranja sa svjetovnim životom. »Svjetski život« kršćanskog učenja praćen je postepenom institucionalizacijom Crkve koja kasnije postaje važnim dijelom društvene infrastrukture Srednjeg vijeka, odnosno moralna legitimacija feudalnog društva, nužno praćena upletenošću u svjetovnu borbu za moć. ${ }^{3}$ To razdoblje kršćanstva završava u ispraznosti formalizma i pokazuje da se od početne potrage za individualnošću došlo na poziciju običajnosti te na bitan način suspendiralo istinsko moralno izražavanje. Finale toga procesa, kada je riječ o katoličanstvu, predstavljala je trgovina indulgencijama, kao krajnje neduhovna praksa koja je potirala moralno unutarnje iskustvo i odgovornost. Reformacija se zato javlja kao veliki pokušaj da se stvar vrati na početak, između ostalog i kroz namjeru da se obnovi moralni individualizam, što je imalo brojne posljedice na tadašnju društvenost.

5.

Nakon srednjovjekovnog etabliranja Crkve kao »kolektivne savjesti« i izrazite institucionalizacije vjere te njenog suštinskog svođenja na običajnosnu moć, s Lutherovim učenjem događa se reafirmacija principa (moralnog) individualizma na religijsko-teološkoj osnovi, na vrlo sličan način onom koji je zagovaran u Kristovu učenju. ${ }^{4}$ Lutherova, a potom i

3 »Tradicionalno-staleško učenje o državi polazi od jedinstva prirode i društva, i u pojmu prirodnog zakona, kako je učio Toma Akvinski, obuhvaća običaje i prirodu, pravo i religiju. Društveni poredak je prirodni poredak, a njegova se prirodnost izražava u hijerarhijskim staleškim odnosima u čijim okvirima svi žive i čiju sudbinu svi dijele.« (Tadić, 1972, 25-26)

${ }^{4}$ Poznato je da su u sferi religije, posebno u njenom monoteističkom vidu, razvijani koncepti vezani za regulaciju moralnog djelovanja. Iako ti koncepti pripadaju mediju drugačijem od filozofskog, od značaja su za etiku kao filozofsku disciplinu upravo zbog toga što se odnose na pitanje moralne individualizacije. To je osnovno pitanje kojim se od svojih početaka bavila etika. U sferi »religijske svijesti« razumijevanje čovjeka prenosi se na njegovu duševnost (srce, gr. kardia, lat. cor) koja treba, posredovana božanskom po- 
Calvinova reafirmacija individualnosti, predstavljala je značajan segment stvaranja idejnog rudimenta koji je kasnije, kroz brojne meandre povijesnog zbivanja, donosio sasvim novu sliku stvarnosti. Ipak, uz značajne sličnosti s postavkama Kristova učenja, različit je dakako povijesni trenutak u kojemu nastaje Lutherovo učenje. U pokušaju reaktualizacije izvornog kršćanstva, protestantizam je svojim postavkama o individualnosti, radu, državi itd., odgovarao nadolazećim procesima, odnosno rastakanju idejno-praktičkog okvira Srednjeg vijeka. Također, značaj protestantizma ogleda se i u odrješitom zagovaranju prava pojedinca (njegove savjesti) na odlučivanje o onome što je istinito u religijskom smislu.

U kontekstu naše teme, važno je spomenuti Lutherovo razumijevanje odnosa Crkve i države, koje je in praxi odgovaralo njemačkim kneževima. Oni su to učenje prihvaćali zbog svojih interesa, nastojeći se emancipirati od utjecaja katoličke crkve. Za razliku od katoličke pretenzije na primat nad državnom vlašću, Luther je zagovarao suštinsko razgraničenje vjerske i političke sfere. Smatrao je da se osnovni religijski interes ogleda u okretanju vjeri i napredovanju u njoj, dok regulaciju sfere »prozaičnih ljudskih stvari« treba prepustiti državi. Država, smatra Luther, kao samostalna svjetovna moć ima svoj djelokrug; ona treba »mačem《 gušiti zlo i održavati poredak (Tadić, 1972, 44-60). U kontekstu teme sekularizacije, protestantski stav o »samostalnom političkom pravu vladara« može se sagledati kao značajan segment legitimacije državne sfere.

Protestantizam je uzrokovao veliki potres u srcu tadašnje Europe, potres koji je bio praćen žestokim religijskim sporovima i sukobima. ${ }^{5}$ To je neminovno, s obzirom na razornu snagu sukoba, stvorilo potrebu nalaženja novih rješenja u pogledu koegzistencije različitih religijskih pravaca. ${ }^{6}$

moći, pronaći istinski pravac moralnog djelovanja. Moralna individualizacija, kao sastavni dio općeg procesa individualizacije, podrazumijeva načelnu priznatost prava pojedinačne moralne namjere, moralnog uvjerenja, moralnog izbora itd., odnosno uvaženost mogućnosti moralnog samorukovodstva. Sadržaj Novog zavjeta u kojemu je izloženo Kristovo učenje može se sagledati kao jedna od najvažnijih epohalnih točaka rasprave o moralnoj individualizaciji. Na primjeru Kristova učenja i Pavlove teologije uočavamo kako se pitanje moralne individualizacije iz filozofskog medija (antičke koncepcije) pomaknulo u religijski medij, odnosno iz medija epistemičnosti ka mediju »duševnosti« u kojemu se tražilo uporište za orijentire moralnosti i istinskoga života. Moralno samoudubljivanje je, prema Kristu, trebalo za rezultat imati okretanje ka bogu, odnosno nalaženje boga u ljudskom srcu.

${ }^{5}$ Ovdje prije svega mislimo na Bartolomejsku noć (28. 8. 1572.) i ubojstva hugenota.

${ }^{6} \mathrm{U}$ tom pogledu važan je dokument poznat pod nazivom Nantski edikt (1598). 
6.

Uz idejne transformacije u sferi religijskog mišljenja, značajne promjene događale su se i u sferi novovjekovne filozofije i znanosti. One su nesumnjivo imale veliki utjecaj na oslobađanje od srednjovjekovnoteološkog idejnog okvira te su doprinijele procesu sekularizacije. U tom pogledu, važan dio predstavljala je afirmacija određenja prirode te traženje adekvatne metode njenog proučavanja (redefiniranje svrhe i usmjerenja znanosti). Veliko otkriće Zapada predstavljao je

»... izum imanentnog poretka u prirodi, čije se djelovanje može sustavno shvaćati i objašnjavati na osnovu njega samog, ostavljajući pri tom otvorena pitanja ima li ovaj poredak dublje značenje i može li se iz njega izvesti postojanje transcendentnog stvoritelja.« (Taylor, 2011, 25)

Relativizacija važnosti transcendensa kao središta legitimacije »svijeta«, a u okviru toga i "praktičkog svijeta«, donosila je drugačije vrednovanje smisla života, interesa, moralnih dužnosti itd. ${ }^{7}$ Kada je riječ o novovjekovnoj praktičkoj filozofiji, značajan interes pridaje se proučavanju ljudske prirode, što je praćeno i nastankom teorija prirodnoga prava i traganjem za novim legitimacijama društvenosti. To je u velikoj mjeri bilo motivirano promjenama u tzv. materijalnom životu i ujedno donosilo zametke građanske individualnosti, uključujući nagovještaj novih formi moralnoga djelovanja, ekonomske slobode, konstitucije države itd.

Filozofska refleksija praktičke sfere prati novovjekovni proces relativnog osamostaljivanja praktičkih područja (njihovo profiliranje) odnosno postepeno izdvajanje iz srednjovjekovnog idejno-praktičkog okvira (emancipacija moralne, ekonomske, političke sfere). Prvi vjesnik rastakanja aristotelovskog jedinstva etika-ekonomija-politika, jedinstva koje je na specifičan način čuvao kršćansko-srednjovjekovni »transcendentni okvir« bio je Niccolo Machiavelli. Proslavljeni firentinski autor izrazio je uvjerenje da u susretu morala i politike neminovno dolazi do pobjede političkih rezona, koncentriranih prije svega u tehnici vladanja i ultimativnoj svrsi održanja na vlasti. Suštinski, riječ je o oglašavanju činjenice da je srednjovjekovno-kršćanski idejni okvir koji je vjekovima održavao, barem u načelnom smislu, cjelinu praktič-

${ }^{7}$ U ovom temeljnom metodskom zaokretu, Machiavellijevo djelo paradigmatično je kao »filozofski zaokret k propitivanju uvjeta svakodnevnog života, proširenog i na pitanje vlasti«. (Raunić, 2005, 146) 
kog života i davao joj legitimitet, prestao biti djelotvoran. Machiavelli ukazuje na posebnost sfere politike (države) i rezona koji vladaju u njoj, smatrajući ih u značajnoj suprotnosti religijskim moralnim regulama. ${ }^{8}$

Nešto kasnije, značajan idejni prekid s dugotrajnom dominacijom kršćanskih postavki donijela je i filozofija Thomasa Hobbesa (Sadžakov, 2012). Hobbes smatra da »ne postoji takav finis ultimus, krajnji cilj, niti summum bonum, najviše dobro, kao što se govori u knjigama starih filozofa morala« (Hobbes, 1991, 110). Tim stavom Hobbes negira i važnost kršćanske koncepcije u pogledu konstitucije moralnog stava, a posredno i u pogledu reprodukcije društvenosti. Zadatak »istinske filozofije morala « ogleda se $\mathrm{u} »$ proučavanju zakona prirode« koje treba rezultirati novim shvaćanjem pojmova dobra i zla (Hobbes, 1991, 168). Svoju pažnju Hobbes je usmjerio na ono što mu se činilo presudnim - pojam samoodržanja. Prema njegovu mišljenju, ključni pokretači društvenosti su borba za preživljavanje, odnosno težnja ka moći i primarna realizacija vlastitih potreba i interesa. Nadmetanje tijela i pripadnih egoizama u prirodnom stanju ima svoj nastavak, u modificiranoj formi, u društvenom odnosno državnom stanju. ${ }^{9}$ Hobbes je u okviru svoje koncepcije naglasio da relativizacija imperativa tijela u prirodnome stanju (težnja ka moći, »temeljni« egoizam) vodi u osnivanje države. Svrha država ogleda se u regulaciji različitih ljudskih interesa i potreba. Kao središte praktičke stvarnosti, ona predstavlja isključivo »ljudsku tvorevinu«, daleko od shvaćanja njene funkcije kao »instrumenta« za ostvarenje nekih viših, »spiritualnih « ciljeva. ${ }^{10}$ Hobbesova filozofija svojevrsni je teorijski izraz apsolutizma, nasuprot koncepciji tzv. staleške monarhije.

${ }^{8}$ Jedna od ključnih razlika Machiavellijevih postavki u odnosu na Luthera ogleda se i u tome što Machiavelijeva namjera nije bila usmjerena ka »spašavanju« kršćanstva i prave vjere, već se njegovo djelo može uzeti kao izraziti primjer deteologizacije djelovanja odnosno relativizacije značaja kršćanskog »transcendentnog okvira«. O Machiavellijevu stavu prema religiji u: Plamenatz, 2009, 88-92.

${ }^{9}$ Jedan od osnovnih argumenata vezanih uz nesigurnost (neodrživost) prirodnoga stanja je, prema Hobbesovu mišljenju, činjenica da svatko svakoga može ubiti. Tijelo drugog se u prirodnome stanju pokazuje prije svega kao fizička prijetnja, a u društvenome stanju kao prijetnja realizaciji raznovrsno formiranih egoističkih interesa i svrha (podjela dobara, moći, ekonomskih interesa).

${ }^{10}$ O Hobbesovim pogledima na religiju u: Manent, 2001, 37-61. Odstranivši transcendentne ciljeve, ovaj autor je društvenost shvatio kao permanentno »vrenje« egoističkih interesa. Naglašavajući egoizam kao čovjekovu presudno determinirajuću karakteristiku - koja se može samo stišati, a nikad sasvim odbaciti - Hobbes ističe osnovu od koje se mora poći kada se govori o individualnosti (interesima; prije svega u njenom ekonomskom vidu). Hobbesova pozicija često se smatra pozicijom tzv. racionalnog egoizma (Kavka, 1986, 29-46). 
7.

Hobbes je svojim postavkama o prirodnome stanju, samoodržanju, prirodnom pravu i prirodnom zakonu, egoizmu i državi, otvorio ne samo pitanja političke nego i ekonomske regulacije. Kada je riječ o ekonomskoj regulaciji društvenosti, neizostavno se mora govoriti i o moralnim konotacijama koje prate ovu osnovnu sferu reprodukcije ljudskog života. Spomenimo ovdje da su rasprave o moralnim regulama koje se odnose na ekonomsko djelovanje imale svoje značajno mjesto u skolastici (razumijevanje rada, dostojanstvo prosjačenja, zelenašenje itd.) i bitno utjecale na određivanje moralnih kriterija tadašnjega vremena (Tawney, 1979). Te su regule kasnije, na mnogo načina, postale preprekom drugačijim vizijama društvenoga razvoja te se napor pojedinih novovjekovnih mislitelja u velikoj mjeri može sagledati kao posredno ili neposredno razgrađivanje dogmatskih postavki srednjovjekovnog idejnog sustava koje su se odnosile na ekonomsko djelovanje.

U tom je pogledu vrlo značajno stajalište praktičke filozofije Johna Lockea. Njegova filozofija predstavlja svojevrsnu razmeđu dvije slike svijeta, srednjovjekovne i novovjekovne. Lockeove ideje suštinski su nagovještaj druge, uz puno tributa prvoj. ${ }^{11}$ To je, između ostalog, primjetno i u Lockeovu opredjeljivanju za deizam, kao svojevrsni oblik »racionaliziranog kršćanstva«. Prema Lockeovu mišljenju, prirodni zakon istovremeno je iskaz objavljene božje volje, ali i nešto korespondentno ljudskome razumu. ${ }^{12}$ Engleski autor se, kako smatra Taylor, priklanja deističkom stajalištu koje potvrđuje teološke postavke ne negirajući pritom važnost i potencije ljudskoga razuma. Kod Lockea se

${ }^{11}$ Kompromisnost Lockeova izvođenja može se uočiti i u pogledu njegova učenja o vlasništvu koje predstavlja nešto novo ne samo u odnosu na teološku nego i u odnosu na filozofsku tradiciju, a opet ujedno, u određenim segmentima, predstavlja i izvjesno ponavljanje stavova iznijetih unutar obje tradicije. Svoje opravdanje rada, a potom i opravdanje vlasništva i prava na egoizam, Locke gradi ukazujući na analogiju između ljudskog i božanskog stvaranja. O različitim interpretacijama Lockeova razumijevanja rada i vlasništva u: Waldron, 1988, 137-253; Plamenatz, 2009, 275-281. Tuli smatra da je ključ za razumijevanje Lockeova rješavanja problema rada i vlasništva njegov opis posebne relacije između boga kao stvoritelja i čovjeka kao njegova djela (Tully, 1980).

${ }^{12}$ Moralne dužnosti izvedene su iz prirodnoga zakona koji je božanski, ali podrazumijeva i racionalna pravila koja su kao takva obvezna za sva racionalna bića. Drugim riječima, zakon prirode normativan je zbog toga što je božja zapovijed, ali se može spoznati i razumom, tj. ne spoznaje se isključivo otkrivenjem. »Deističko stajalište odgovara Lockeovim težnjama jer, nasuprot protestantskoj ortodoksiji, omogućuje da se racionalno slijedi Božja volja iskazana u prirodnom zakonu...« (Pannenberg, 2003, 124-125) 
također kroz čitav niz rješenja nastavlja afirmacija »kalkulativnog razuma« koja je potencirana i kod Hobbesa. Ta afirmacija je suštinski, po svojim posljedicama, predstavljala opreku dotadašnjem teološkom pristupu i, između ostalog, utjecala na drugačije shvaćanje formi moralnog odnošenja.

Neka od važnih obilježja Lockeova učenja su naglašavanje prava individualnosti, posebno u sferi ekonomske slobode (povezanost određenja vlasništva i slobode), naglašavanje važnosti racionalne kompetencije pojedinca nad vlastitim životom te novo utemeljenje moralnih dužnosti. ${ }^{13}$ Engleski autor, nastojeći opravdati važnost privacije, govori o potrebi etabliranja mehanizama zaštite individue u odnosu na državu, ali i mehanizama zaštite od drugih individua. U tome kontekstu Locke govori i o pravu na slobodan izbor religijskoga stajališta te o važnosti tolerancije u pogledu religijskih pitanja (Locke, 2015).

Nakon Lockea, autori poput Mandevillea i Smitha, shodno povijesnom trenutku koji imaju »pred očima«, pišu mnogo otvorenije u pravcu afirmacije stajališta privacije (posebno ekonomske slobode, egoizma), u najvećoj mjeri relativizirajući važnost religijskih moralnih regula i postavki teoloških koncepcija. Oni nedvosmisleno iskazuju stav da privatna sfera kao izraz slobode i pokretač društvenog blagostanja (posredovan slobodnim tržištem) ne smije biti sputana intervencijom države i religije. Spomenuti autori, kao i Locke prije njih, teorijski opravdavaju moralna stajališta koja su kompatibilna građanskom shvaćanju sfere ekonomije.

8.

U prethodnim poglavljima pokušali smo naznačiti neke od aspekata transformacije idejnih osnova europske društvenosti koji su u vezi s državno-političkom, ekonomskom i religijskom sferom, a ujedno imaju i značajnu relevantnost za proces sekularizacije. U ovome poglavlju razmotrit ćemo, u kontekstu osnovne teme našega rada, Kantovu poziciju kao paradigmatično stajalište u području etike.

Kada je riječ o odnosu njemačkog mislitelja prema religiji i određenju boga, treba svakako naglasiti da se radi o filozofskom, a ne o teološkom pristupu. Također, treba razlikovati Kantov stav prema re-

${ }^{13}$ Naglašavanje važnosti prava privatnosti i brige za vlastiti interes koje podrazumijeva smanjenje obzira prema bližnjima koje je, barem načelno, zagovaralo kršćanstvo. 
ligiji (vjeri, Crkvi) od njegova razmatranja određenja boga u okviru filozofskog sustava, odnosno zasnivanja etičke pozicije. Općenito govoreći, određenje boga u Kantovoj filozofiji figurira kao pokušaj rješavanja brojnih ambivalentnosti i teškoća u zasnivanju njegova misaonog sustava (Pannenberg, 2003, 137-145). U okviru ovog teksta nemamo pretenziju šire se baviti tim pitanjem, nego nam je nakana naznačiti neka mjesta Kantova djela koja svjedoče o njegovu stavu prema religijskim postavkama, određenju boga i moralnome stajalištu, s uvjerenjem da oslikavaju pravi smisao njegova mišljenja.

Podsjetimo da Kant u središte svoje etičke koncepcije stavlja pitanje autonomije moralne individue, nastojeći osvijetliti mogućnosti moralnog djelovanja. Na tragu prosvjetitelja, prije svega Rousseaua, ovaj njemački mislitelj govori o samozakonodavstvu volje, odnosno o individui »oslonjenoj « na samu sebe u moralnome smislu. ${ }^{14}$ Kantovim poznatim razlikovanjem autonomije i heteronomije suštinski se relativizira zasnivanje moralnosti na teološkoj osnovi. Kantova namjera u pogledu traženja pouzdanih kriterija morala nije usmjerena u pravcu opravdanja »teoloških istina«, već k ispitivanju mogućnosti autonomije ljudskoga djelovanja kao umskog djelovanja. Priznati ono što Kant naziva autonomijom moralnog djelatnika znači »priznati da vanjski autoritet, pa makar i božanski, ne može pružiti nikakav kriterij za moralnost« (MacIntyre, 2000, 217). Umska »dobra volja« podrazumijeva pravila koja mogu obvezati sva umna bića, čak i bez pozivanja na božanski autoritet. Da bi se moralnost zasnovala na umski način, mora se, prema Kantovu mišljenju, iz motivacije »dobre volje« isključiti sve što dolazi iz područja »afektivnosti«. Pored ostalog, za Kanta ostaje problematično i kršćansko podizanje ljubavi na razinu moralnog principa. Smatra da se istinski kriteriji moralnoga djelovanja mogu naći samo upućivanjem na um, a ne na osjećaje ili »srce« moralnog subjekta kao onog što vodi bogu kao moralnom apsolutu. Zbog svega navedenog može se reći da Kantova etika ostaje "paradigmatski i najutjecajniji pokušaj opravdavanja univerzalnih moralnih principa, bez pozivanja na sklonosti ili na teološki okvir« (Singer, 2004, 269).

14 »Podčinjeni smo samo zakonima uma: ovim priznanjem Kant nas oslobađa dominacije teološkog apsolutizma i okova teleologije prirodnog zakona i, na sličan način, uzdiže nas iznad prozaičnih banalnosti učenja o razboritosti. Ljudska bića smiju i moraju povinovati se jedino vlastitome umu; u tome je njihovo dostojanstvo, kao i njihov zahtjevni i tegobni moralni poziv.« (Divjak i Milenković, 2005, 145) 
Kasniji tijek etičke refleksije na mnogo je načina zaboravljao Kantovo naslijeđe i proklamirani umski princip te je principe moralnog djelovanja vezivao za drugačije izvore. ${ }^{15}$ Međutim, i u takvim pokušajima uočava se relaksiranost od religijskog načina zasnivanja moralnoga stajališta.

9.

Pored sfera morala i ekonomije, koje smo razmotrili u kontekstualnoj vezi s pojmom sekularizacije, treba spomenuti i sferu koja je »proglasila« pobjedu sekularizacije, a to je sfera prava. Pravna regulacija područja religijskih iskazivanja imala je značajne reperkusije u pogledu društvenosti. U kontekstu religijskoga pitanja, zakonske osnove određene sekularizacijskim tekovinama predstavljaju rezultat traženja modusa koegzistencije različitih vjerskih opredjeljenja, odnosno izraz potrebe da građanski svijet izgradi modele tzv. religijske tolerancije. To je, kako se pokazalo, nužno podrazumijevalo relativizaciju određenih formi vjerskog utjecaja u društvenost (Raunić, 2006, 269-287). Pored ostalog, pravnim etabliranjem sekularizacijskih postavki nesumnjivo je omogućena i nova stvarnost moralnog iskazivanja jer je u čitavom nizu pitanja stvoren slobodniji kontekst moralne »infrastrukture« (pravo savjesti, uvjerenja, slobodnog opredjeljivanja povodom moralnih pitanja itd.). Općenito gledajući, "pravo« moralnosti je, kroz oslobađanje od »nanosa《 religijskog (kao i raznih tipova kolektivizma i patrijarhalnosti) donijelo proširivanje mogućnosti izgrađivanja moralnog identiteta.

Sekularizacija se neizbježno razumije preko tzv. javnog prostora. U njemu je, shodno etabliranju sekularizacijskih postavki, »Bog odsutan kao bilo kakva referenca na najvišu stvarnost« (Taylor, 2011, 12). Drugačije rečeno, to znači da nas

»... prilikom djelovanja u raznim sferama - ekonomskoj, političkoj, kulturnoj, obrazovnoj, profesionalnoj, rekreativnoj - norme i principi koje slijedimo, stavovi koje zastupamo, ne povezuju s Bogom, ili nekom drugom religijom.« (Taylor, 2011, 12)

Argumenti na osnovu kojih djelujemo u različitim praktičkim sferama posjeduju specifičnu posebnost (maksimalna dobit u ekonomiji, najveća korist za najveći broj u političkoj sferi). Ovo je

${ }^{15}$ Spomenimo ovdje princip zadovoljstva koji se nalazi u središtu etičke koncepcije utilitarizma (J. Bentham, J. S. Mill). 
»... upadljiv kontrast ranijim razdobljima kada je kršćanska vjera postavljala autoritativne propise, često kroz usta svećenstva, koji se nisu mogli lako ignorirati o bilo kojem području da se radi; recimo, zabrana zelenašenja ili obveza pridržavanja pravovjernosti.« (Taylor, 2011, 12)

Umjesto jednog čvrstog moralnog okvira izgrađenog na teološkim postavkama, građanski svijet donosi novum koji se ogleda u tome da se moderna moralna stvarnost formira kao rezultanta sučeljavanja različitih moralnih koncepcija, ideja, stavova, interesa itd. Oni se posreduju na »moralnoj agori« formirajući stvarnost moralnog odnošenja. Sekularizacija je, dakle, između ostalog, strukturno omogućila prijelaz ka modernom moralnom pluralizmu. Takav kontekst pokazao se kao najpogodniji za upravljanje vlastitim životom (moralnim izborima) u argumentiranoj atmosferi, umjesto vođenosti prinudom, monopolom na moralna pitanja i razumijevanjem religijskoga koncepta kao jedinog puta ka duhovnosti i moralnosti. Drugim riječima, pokazalo se da religijske postavke počivaju na odveć nesigurnim osnovama da bi određivale moralnost svih članova jednoga društva. U tom pogledu, sekularizacija se zaista može sagledati kao pobjeda temeljnih postavki racionalizma, liberalizma i prosvjetiteljstva. Ona nikako ne može biti tumačena kao »zavjera«, »modernizacijska izmišljotina«, »dio matrice neoliberalističke mitologije suvremenog svijeta u kojemu se hoće da jedan obrazac bude obvezan za sve« (Đorđević, 2006, 409), »nesloboda« ili kao nešto što je uništilo i uništava »religijska prava i slobode«. Naprotiv, sekularizacija je ta prava i slobode svela na »razumnu mjeru u okviru moralnog pluralizma i načina reprodukcije građanskoga svijeta. Drugim riječima, time je omogućena koegzistencija različitih religijskih pravaca, kao i stvaranje mogućnosti za slobodno izražavanje agnosticizma i ateizma (Cliteur, 2010, 14-69). Uz to, sekularizacija je donijela i mogućnost da oni koji se izjašnjavaju kao vjernici izaberu, shodno vlastitoj procjeni, opseg prakticiranja religijskih regula, poštivanja moralnih dužnosti proklamiranih od strane religije itd. Radi se o onome što se u literaturi naziva »minimalnom religijom« odnosno pravom vjernika na samostalno određivanje religijskog identiteta.

10.

$\mathrm{Na}$ kraju rada, nakon razmatranja vezanih uz povijesno etabliranje sekularizacije, osvrnimo se na određena pitanja i dileme aktualnog trenutka. Kada je riječ o etabliranosti sekularizacije na globalnoj razini, 
može se primijetiti da je stanje vrlo različito, ovisno o civilizacijskoj razini određenog podneblja. Dok posebno europske države karakterizira relativno dugo opstojanje sekularizacijskih tekovina, postoje brojne države u kojima je sekularizacija polovično izvedena ili je utjecaj religijskih zajednica toliko velik da se ne može govoriti niti o približnom zadovoljavanju parametara koje ona podrazumijeva. Čak i kada je riječ o europskim državama, svakodnevni život i problemi koje on donosi stvaraju trajnu potrebu promišljanja postojećeg sekularizacijskog okvira, njegove pravne i moralne osnove te odgovaranja na brojne aktualne dileme. Suvremeni svijet bremenit je čitavim nizom problema koji su povezani s religijskim uvjerenjima i njihovim izražavanjima te se potraga za mehanizmima njihovog posredovanja pokazuje nužnom za opstanak i unaprjeđenje društvenosti. Jedan od problema svakako je vezan za tzv. vjerski fundamentalizam i »političku instrumentalizaciju religijskog nasilnog potencijala« (Habermas). Radi se kako o pretenzijama određenih religijski pravaca na zauzimanje značaja i uloge koju su imali u razdoblju prije sekularizacije, tako i o grubim zloporabama religijskih učenja. Konkretna praksa pokazuje brojne primjere drastičnih konsekvenci takvih zloporaba. ${ }^{16}$ Sve to iznova otvara pitanje utvrđivanja standarda društvenosti, propitivanja granica iskazivanja pravnih i moralnih sloboda i uvjerenja, odnosno razmatranje dileme o tome kada nečijim djelovanjem (motiviranim religijskim učenjem) počinje ugrožavanje slobode drugih.

Još jedan važan aspekt u kontekstu teme odnosa sekularizacije i morala vezan je i uz tzv. bioetičke probleme. Poznato je da su znanstvenotehnološka dostignuća uzrokovala čitav niz specifičnih moralnih dilema, nepoznatih $u$ ranijim povijesnim razdobljima. Jedna od njih je $i$ ta je li sve što je moguće (tehnički izvedivo) istovremeno i moralno dopustivo (opravdano). Spomenuta dostignuća utjecala su na konstituiranje novih polja znanstvenog promišljanja i istraživanja, pri čemu ponajprije mislimo na bioetiku kao interdisciplinarno područje. Treba podsjetiti na to da su i različiti teološki pravci uključeni u rasprave o bioetičkim pitanjima poput eutanazije, pobačaja, kloniranja, darovanja organa, surogat-majčinstva, ekoloških problema itd. Nastojeći kroz dogmatske sadržaje razmotriti ova osjetljiva pitanja, religijska bioetika ukazuje na brojne opasnosti koje donosi moderna znanstveno-teh-

${ }^{16}$ Poznati su primjeri fatve kojom je doveden u pitanje život pisca Salmana Rushdieja, osude na smrt i ubojstava zbog karikatura u novinama itd. 
nološka ekspanzija. U okviru religijskog bioetičkog pravca naglašava se potreba kontrole svega onog što narušava »svetost « ljudskog života (Mitchell, 1980, 93-136). Međutim, značajan problem može se uočiti u onome što se iz pozicije religijsko-dogmatskih postavki često zagovara kao rješenje bioetičkih pitanja. Sve to itekako zadire u sekularizacijski formirani kontekst društvenosti, kao i u moralna mjerila građanskoga svijeta (Tristram Engelhardt, 2011). Nesumnjivo je legitimno da religijski pravci imaju svoj stav o bioetičkim pitanjima i da nastoje ponuditi orijentir djelovanja onima koji se izjašnjavaju kao vjernici. Ipak, pritom postoji dosta problematičnih reperkusija takve namjere. ${ }^{17}$ Smatramo da je jedna od osnovnih ona koja se tiče proklamirane svrhe bioetike, a to je rješavanje konkretnih problema konkretnih ljudi. Čini se da insistiranje religijske bioetike na rješenjima isključivo usklađenim $\mathrm{s}$ dogmatskim sadržajem vrlo često donosi sužavanje prostora argumentirane rasprave odnosno zanemarivanje kompleksnosti problema koji se tiču slobodnoga izbora, zdravlja ljudi, unaprjeđenja njihove sreće, olakšanja patnje itd. Posebno veliki problem predstavlja pretenzija religijske bioetike na općeobvezujuće važenje njenih stavova, dakle obvezivanje i onih koji nisu vjernici. ${ }^{18}$ Primjera radi, opasnost te težnje ogleda se i u pridruživanju zahtjevima da se pobačaj zakonski zabrani. Zbog svega navedenog, može se ustvrditi da nikakvi pozivi ka religijskoj obnovi koji bi podrazumijevali vraćanje na pred-moderno stanje (desekularizacija), uključujući i religijske prijedloge u pogledu bioetičkih problema, ne mogu biti alternativa onome što u europskih okvirima već dugo opstaje pod nazivom sekularizacija. Realizacija spomenutih prijedloga neminovno bi vodila sužavanju modernih moralnih sloboda te zato takve pojave mogu biti okarakterizirane i kao svojevrsna forma vjerskog fundamentalizma.

${ }^{17} \mathrm{U}$ praksi postoji čitav niz primjera kolizije religijskih uvjerenja i zakonskih obveza. Jedan od njih vezan je uz liječničku profesiju.

${ }^{18}$ Ovo se odnosi na čitav niz pitanja, među ostalim i na pitanje seksualnih sloboda. 


\section{Literatura}

Boisset, Jean (1985), Protestantizam: kratka povijest, Zagreb: Kršćanska sadašnjost. Borkenau, Franz (1983), Prelazak sa feudalne na građansku sliku sveta, Beograd: Komunist.

[Brown, Peter] Braun, Piter (2010), Uspon hrišćanstva na Zapadu: trijumf i raznolikost 200-1000. godine, Beograd: Clio.

Cliteur, Paul(2010), The Secular Outlook: In Defense of Moral and Political Secularism, Chichester: Blackwell Publishing. http://dx.doi.org/10.1002/9781444325324

Đorđević, Mirko (2006), Sjaj i beda utopije, Beograd: Srpska reč.

[Epstein, Mikhail] Epštejn, Mihail (2009), Filozofija tela, Beograd: Geopoetika.

Franzen, August (1983), Pregled povijesti Crkve, Zagreb: Kršćanska sadašnjost.

[Hobbes, Thomas] Hobs, Tomas (1991), Levijatan, Niš: Gradina.

Kavka, Gregory S. (1986), Hobbesian Moral and Political Theory, Princeton: Princeton University Press.

[Cohen, Moris i Nagel, Ernest] Koen, Moris i Nejgel, Ernest (1965), Uvod u logiku i naučni metod, Beograd: Zavod za izdavanje udžbenika SRS.

Divjak, Slobodan i Milenković, Ivan (prir.) (2005), Moderno čitanje Kanta, zbornik, Beograd: Zavod za udžbenike i nastavna sredstva.

[Lynch, Joseph] Linč, Džozef (1999), Istorija srednjovekovne crkve, Beograd: Clio.

[Locke, John] Lok, Džon (2015), Pismo o toleranciji, Novi Sad: Eden kuća knjige.

[MacIntyre, Alasdair] Makintajer, Alaster (2000), Kratka istorija etike, Beograd: Plato.

[Manent, Pierre] Manon, Pjer (2001), Intelektualna istorija liberalizma, Beograd: Stubovi kulture.

Mitchell, Basil (1980), Morality, Religious and Secular: The Dilemma of the Traditional Conscience, New York: Oxford University Press.

[Pannenberg, Wolfhart] Panenberg, Volfhart (2003), Teologija i filozofija, Beograd: Plato.

[Plamenatz, John] Plamenac, Džon (2009), Čovek i društvo, Beograd: Službeni glasnik.

Raunić, Raul (2005), Pretpostavke liberalnog razumijevanja čovjeka, Zagreb: Hrvatsko filozofsko društvo.

Raunić, Raul (2006), »Etička, odgojna i politička vrijednost tolerancije«, u: Polić, Milan (ur.), Filozofija i odgoj u suvremenom društvu, Zagreb: Hrvatsko filozofsko društvo, str. 269-278.

Sadžakov, Slobodan (2006), Novozavetni moral, Novi Sad: Filozofski fakultet Novi Sad. 
Sadžakov, Slobodan (2012), »Hobbes i problem egoizma«, Filozofska istraživanja, 32(1), str. 63-77.

Tadić, Ljubomir (1972), Tradicija i revolucija, Beograd: Srpska književna zadruga.

[Taylor, Charles] Tejlor, Čarls (2011), Doba sekularizacije, Beograd: Službeni glasnik.

[Tawney, Richard Henry] Toni, R. H. (1979), Religija i uspon kapitalizma: istorijska studija, Beograd: Prosveta.

Tristram Engelhardt, Hugo (2011), Bioethics and Secular Humanism: The Search for a Common Morality, Wipf \& Stock Publishers.

Tully, James (1980), A Discourse on Property: John Locke and His Adversaries, New York: Cambridge University Press.

http://dx.doi.org/10.1017/CBO9780511558641

[Singer, Peter] Singer, Piter (ur.) (2004), Uvod u etiku, zbornik, Sremski Karlovci / Novi Sad: Izdavačka knjižarnica Z. Stojanovića.

[Veyne, Paul] Ven, Pol (2013), Kada je naš svet postao hrišćanski: 312-394, Novi Sad: Mediterran publishing.

Waldron, Jeremy (1988), The Right to Private Property, Oxford: Oxford University Press. http://dx.doi.org/10.1093/acprof:oso/9780198239376.001.0001

\title{
SECULARIZATION AND MORALITY
}

\author{
Mihael Antolović, Slobodan Sadžakov
}

Even though the legacy of secularization has been established as an integral part of contemporary society, numerous tendencies with the aim to challenge and invalidate it are also existent. Those tendencies, with possible harmful consequences, include the idea that secularization does not stand for something indisputable. Therefore it seems necessary to recall what its legitimate basics are, primarily as it is the topic that is not solely an academic issue but also an important factor in terms of organization and quality of a daily life. In this paper we will particularly reflect on ethical aspects of secularization, i.e. the relationship between secularization and morality.

Key words: morality, secularization, law, religion, Christianity 